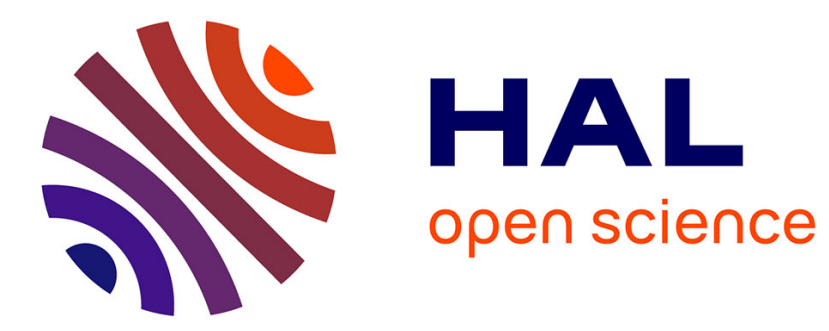

\title{
Nutritional quality of organic rice grown on organic composts
}

\author{
Supradip Saha, A.K. Pandey, K.A. Gopinath, R. Bhattacharaya, S. Kundu, \\ H.S. Gupta
}

\section{- To cite this version:}

Supradip Saha, A.K. Pandey, K.A. Gopinath, R. Bhattacharaya, S. Kundu, et al.. Nutritional quality of organic rice grown on organic composts. Agronomy for Sustainable Development, 2007, 27 (3), pp.223-229. hal-00886358

\section{HAL Id: hal-00886358 https://hal.science/hal-00886358}

Submitted on 1 Jan 2007

HAL is a multi-disciplinary open access archive for the deposit and dissemination of scientific research documents, whether they are published or not. The documents may come from teaching and research institutions in France or abroad, or from public or private research centers.
L'archive ouverte pluridisciplinaire HAL, est destinée au dépôt et à la diffusion de documents scientifiques de niveau recherche, publiés ou non, émanant des établissements d'enseignement et de recherche français ou étrangers, des laboratoires publics ou privés. 


\title{
Nutritional quality of organic rice grown on organic composts
}

\author{
Supradip SAHA*, A.K. PANDEY, K.A. Gopinath, R. BhatTACHARAYA, S. Kundu, H.S. GuPtA \\ Vivekananda Institute of Hill Agriculture, Almora, UA - 263 601, India
}

(Accepted 19 December 2006)

\begin{abstract}
The use of organic nutrient sources in improving crop quality can be a viable alternative to traditional farming. Organic farming encourages the reduction of agrochemicals and promotes soil conservation principles. Although crop quality depends on several factors, among which the nutrient source plays a great role, there is little information available on how rice quality is affected by different organic composts. Here we grew aromatic rice on two levels of four organic composts made from kudzu vine (Pueraria lobata) at 5 and $10 \mathrm{Mg}^{-1}$, Urtica sp. (nettle) at 5 and $10 \mathrm{Mg} \mathrm{ha}^{-1}$, Lantana sp. at 5 and $10 \mathrm{Mg} \mathrm{ha}^{-1}$, winter weeds at 2.5 and $5 \mathrm{Mg} \mathrm{ha}^{-1}$, and two other organic amendments of poultry at 2.5 and $5 \mathrm{Mg} \mathrm{ha}^{-1}$ and farmyard manure at 5 and $10 \mathrm{Mg} \mathrm{ha}^{-1}$. We studied the effect of these organic sources on nutritional and physico-chemical properties, and on the cooking quality of the rice, using a fertilized, chemical treatment as positive control. Our results show that grain yield was significantly influenced by the supply of major plant nutrients. The highest rice yield of $4.0 \mathrm{Mg} \mathrm{ha}^{-1}$ was obtained from the inorganically fertilized treatment. The protein content in grains was the highest, $8.98 \%$, in the inorganic treatment (100:60:40 kg N, P, K ha ${ }^{-1}$ ) and lowest, $7.55 \%$, in the control. Among organic treatments, farmyard manure at $10 \mathrm{Mg} \mathrm{ha}{ }^{-1}$ contributed the least in terms of the protein content of the rice (7.78\%). Significantly higher iron content, of $52.2 \mu \mathrm{g} \mathrm{g}-1$, was recorded with organic fertilization than inorganic fertilization $\left(42.1 \mu \mathrm{g} \mathrm{Fe} \mathrm{g}^{-1}\right)$. However, inorganic fertilization was superior in terms of copper content, of $4.1 \mu \mathrm{g} \mathrm{Fe} \mathrm{g}^{-1}$, compared with organic treatments: 3.1-4.0 $\mu \mathrm{g} \mathrm{Fe} \mathrm{g}^{-1}$. Quality attributes indicated that cooked kernel length was positively correlated with the kernel elongation ratio. Winter weed compost provided comparative benefits for rice yield $\left(3.87 \mathrm{Mg} \mathrm{ha}^{-1}\right)$ and quality in terms of protein $(8.42 \%)$, iron $\left(48.31 \mu \mathrm{g} \mathrm{g}^{-1}\right)$ and head rice recovery (49.39\%) compared with other sources of nutrients. The results of this study suggest that organic nutrient sources can perform comparatively well as regards chemical and physico-chemical properties, and cooking quality of rice, if not better in some parameters than inorganic fertilization.
\end{abstract}

aromatic rice / organic compost / nutritional constituents / phytic acid / physico-chemical properties

\section{INTRODUCTION}

Organic food markets in India are expanding quite fast owing to growing demand for organic food and the high premium it fetches (Patnaik, 1996). Basmati and fine grain aromatic rice have tremendous export value. Organic and inorganic produce differ in quality parameters (Artur and Kjellenberg, 1997; Bourn and Prescott, 2002; Wszelaki et al., 2005) and protein content is found to be more in conventional than organic crops (Worthington, 2001; Magkos et al., 2003). However, the source and the amount of fertilizer application directly influence the level of available nutrients, and indirectly the physiology and chemical content of the plant (Li et al., 2003). There is new research impetus towards improving the nutritional quality of rice throughout the world and the issues surrounding rice quality are increasing day by day (Quyen and Sharma, 2003). Rice grain quality is very complicated, but an important character in many rice production areas of the world, mainly defined by four constituents: namely, milling, cooking, appearance and nutritional quality (Li et al., 2003). Among environmental factors, supply of nutrient sources during the life cycle of the crop also contributes to the physico-chemical quality of the produce (Miller et al., 1980).

\footnotetext{
*Corresponding author: s_supradip@yahoo.com
}

Phytic acid (myo-inositol, 1,2,3,4,5,6-hexakis phosphoric acid), an anti-nutritional factor, is the principal storage form of $\mathrm{P}$ in cereals. It reduces the bioavailability of iron, zinc and calcium. In rice grain, the aleurone layer contributes 90 per cent of the phytic acid. Phytate content can be influenced by genetics, environmental fluctuations, types of soil and fertilizer application (Miller et al., 1980; Hidvegi and Lasztity, 2002). Information about the influence of nutrient sources on the conversion of phosphorous to phytic acid is meager.

The present study includes three types of wasteland vegetation: namely, kudzu vine (Pueraria lobata Willd), nettle (Urtica sp.) and lantana (Lantana camara). Kudzu, a vigorous perennial legume and the other two weeds, lantana and nettle, were used as compost for supply of nutrients. The abovementioned plants are fast-growing weeds in nearby wastelands and can be used as potential soil organic amendment (Sharma et al., 2003). Lantana camara and Pueraria sp. residues have been used to increase $\mathrm{P}$ availability, and ultimately increased crop yield (Nziguheba et al., 2000; Kayuki and Wortmann, 2001; Kolawole et al., 2004). In recent times, a number of different nutrient sources have been used as an alternative to inorganic fertilizer (Hachicha et al., 2006; Mekki et al., 2006).

We hypothesized that applications of organic composts with differential nutrient compositions could enhance the nutritional quality of rice grain. Therefore, a field experiment was set up with the objective of estimating the changes in protein, 
Table I. Nutrient content of manures and amount of nutrients added to rice crop.

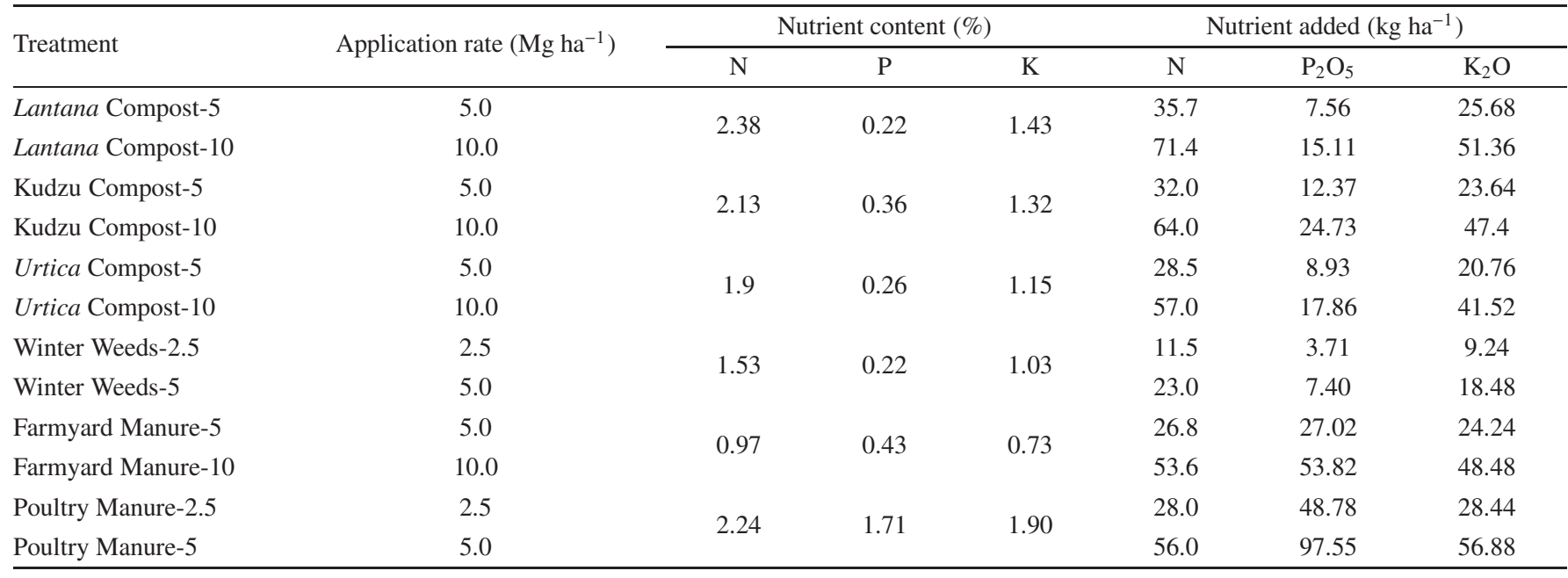

mineral composition, phytic acid and physico-chemical properties of aromatic rice in relation to the application of different organic composts $v i s-a$-vis an inorganically fertilized treatment.

\section{MATERIALS AND METHODS}

\subsection{Chemicals and reagents}

All chemicals and reagents were procured from Merck ${ }^{\circledR}$ India Ltd. Double-distilled water was used throughout the analysis.

\subsection{Instruments}

For protein estimation, an Autoanalyzer (Tecator, Sweden) was used using the Kjeldahl method. Phytic acid and phosphorus contents were estimated colorimetrically using a spectrophotometer (Analytik Jena AG, Germany). For the estimation of potassium, a flame photometer (Systronics 128, India) and for minerals, an atomic absorption spectrophotometer (Analytik Jena AG, Germany) were used. A Satake rice mill and Sigma 12B centrifuge were used for hulling of rice grains and centrifugation, respectively.

\subsection{Experimental site and agronomic practices}

The present experiment was undertaken at the experimental farm of the institute located in Almora, Uttaranchal, India during the rainy season (June-September) of 2003. The experimental plot was situated in the Indian Himalayas (29 36' N, $79^{\circ} 40^{\prime} \mathrm{E}$ and $1250 \mathrm{~m}$ above $\left.\mathrm{msl}\right)$. The soil $(0-15 \mathrm{~cm})$ was silty clay loam, acidic (pH 5.9) in reaction, with $0.09 \mathrm{dS} \mathrm{m}^{-1}$ electrical conductivity, $0.8 \mathrm{~g} \mathrm{~kg}^{-1}$ organic carbon, $414 \mathrm{~kg} \mathrm{ha}^{-1}$ available $\mathrm{N}, 15.8 \mathrm{~kg} \mathrm{ha}^{-1}$ available $\mathrm{P}, 183 \mathrm{~kg} \mathrm{ha}^{-1}$ available

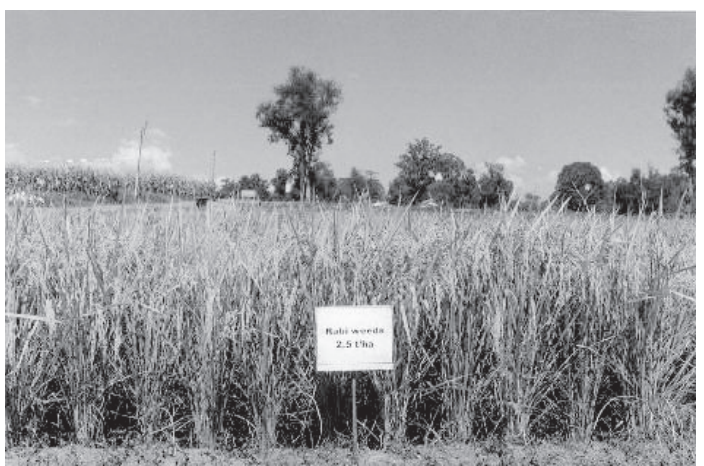

Figure 1. Rice crop in the experimental field.

$\mathrm{K}$ and $1.38 \mathrm{Mg} \mathrm{m}^{-3}$ bulk density. The initial steady state infiltration rate was $18.7 \mathrm{~m} \mathrm{day}^{-1}$.

Fourteen treatments were laid out in a randomized block design with three replicates. The treatments were (i) Non-amended control (ii), (iii) Lantana compost at 5 and $10 \mathrm{Mg} \mathrm{ha}^{-1}$, respectively; (iv), (v) Kudzu compost at 5 and $10 \mathrm{Mg} \mathrm{ha}^{-1}$, respectively; (vi), (vii) Urtica compost at 5 and $10 \mathrm{Mg} \mathrm{ha}^{-1}$, respectively; (viii), (ix) Winter weeds at 2.5 and $5 \mathrm{Mg} \mathrm{ha}^{-1}$, respectively; (x), (xi) Farmyard manure at 5 and $10 \mathrm{Mg} \mathrm{ha}^{-1}$, respectively; (xii), (xiii) Poultry manure at 2.5 and $5 \mathrm{Mg} \mathrm{ha}^{-1}$, respectively; and (xiv) Inorganic (N, P, K were applied at 100, 60 and $40 \mathrm{~kg} \mathrm{ha}^{-1}$, respectively). Organic manures were incorporated into the soil 15 days prior to transplanting of rice. The nutrient contents in different organic manures were analyzed prior to incorporation into experimental plots (Tab. I). The test variety selected was aromatic rice, RP3392-79-45-18-8 (IET11341 × Kasturi) (Fig. 1). Gross plot size for the experiment was $3.00 \mathrm{~m} \times 2.40 \mathrm{~m}$ and the transplanting and harvesting was done on June 10, 2003 and Oct 8, 2003 , respectively. The different organic manures used in this experiment were prepared by composting the chopped plant 
shoots and leaves in a pit for 30-55 days depending on the materials used.

\subsection{Soil sampling and processing}

The soil samples from the surface layer $(0-15 \mathrm{~cm}$ depth) were collected before the start of the experiment. The composite soil samples were air-dried, ground and passed through a 2-mm sieve. Soil samples were digested using a di-acid mixture $\left(\mathrm{HNO}_{3}: \mathrm{HClO}_{4} ; 10: 4 \mathrm{v} / \mathrm{v}\right)$.

\subsection{Soil analysis}

The oxidizable soil organic carbon was determined as per Walkley and Black (1934). Available N, Olsen-P and $\mathrm{NH}_{4} \mathrm{OAc}-\mathrm{K}$ contents were determined by the standard procedures as outlined by Page et al. (1982).

\subsection{Grain sampling and processing}

Rice grains were harvested at maturity and air-dried naturally for further processing. The dried grains were stored at room temperature for three months prior to analysis of physico-chemical properties. The samples were drawn using the quartering procedure (Lees, 1975) and were analyzed for chemical parameters after tri-acid digestion $\left(\mathrm{HNO}_{3}\right.$ : $\left.\mathrm{HClO}_{4}: \mathrm{H}_{2} \mathrm{SO}_{4} ; 10: 1: 4 \mathrm{v} / \mathrm{v} / \mathrm{v}\right)$.

\subsection{Grain analysis}

The protein content was determined as described by the AOAC method using the formula $\mathrm{N} \times 5.95$ (AOAC, 1990). The phytic acid was determined by precipitating it with ferric ion (Wheeler and Ferrel, 1971). Mineral contents were determined after wet ashing with di-acid mixture, concentrated nitric acid and perchloric acid $(1: 1, \mathrm{v} / \mathrm{v})$. The potassium content was determined by flame photometry, while $\mathrm{Fe}, \mathrm{Cu}$ and $\mathrm{Zn}$ contents were analyzed by using an atomic absorption spectrophotometer. Phosphorus was estimated photometrically via development of the phospho-molybdate complex (Taussky and Shorr, 1953).

\subsection{Physico-chemical properties}

The rough rice was dehulled and the brown rice was polished for 75 seconds. This polished rice was ground by using a Cyclotec sample mill. Milled rice out-turn was expressed as per cent of milled rice. A slide caliper was used for measurement of grain length and breadth. Milled rice was then classified, based on length and breadth, as slender (ratio $>3$ ); bold (ratio $2-3$ ); or round $($ ratio $<2$ ) to determine the size and shape of the rice grain. The alkali spreading value was determined according to the procedure of Little et al. (1958). Volumes of cooked and milled rice were measured by the water displacement method. Five grams of milled rice were added to a graduated cylinder containing $50 \mathrm{~mL}$ of water and the change in volume was noted. To measure the volume of cooked rice, $5 \mathrm{gm}$ of milled rice were cooked and then added to the same cylinder to note the change in volume. Cooking time was measured at that time when 90 per cent of the cooked rice was totally gelatinized.

\subsection{Statistical analysis}

Data were statistically analyzed using SPSS (version 10.0) and represented by using Duncan's Multiple Range Test values. Significant differences were determined at the $P<0.05$ level. The results are expressed as the mean \pm standard deviation.

\section{RESULTS AND DISCUSSION}

\subsection{Protein content}

Protein content in dehulled rice grains varied from 7.55 to $8.98 \%$ (Tab. II), which was significantly higher in inorganic than organic treatments. This may be attributed to more availability of nutrients, particularly nitrogen, to the crop in the plots under inorganic treatment. Among organic treatments, application of winter weeds at $5 \mathrm{Mg} \mathrm{ha}^{-1}$ and kudzu compost at $10 \mathrm{Mg} \mathrm{ha}^{-1}$ resulted in significantly higher protein content $(8.42 \%)$ compared with other treatments. Farmyard manure at 5 and $10 \mathrm{Mg} \mathrm{ha}^{-1}$ did not perform well, as both levels were at par with control.

\subsection{Phytic acid and phosphorus}

About 44.91-53.81\% inorganic $P$ was converted into phytic acid and it ranged from 363-419 mg per $100 \mathrm{~g}$ of dehulled grains (Tab. II). Phytic acid content in this aromatic rice line was in the lower range, as reported by Oatway et al. (2001). No distinct trend was observed in total phytic acid content amongst different treatments, which shows that sources and doses of applied nutrients had little significant role in the conversion of $\mathrm{P}$ into phytic acid. Phytic acid content seems to be genetically controlled. However, the conversion of inorganic $\mathrm{P}$ into phytic acid was highest $(53.81 \%)$ in rice grains from nonamended control plots. In contrast, total phosphorus content differed significantly among treatments, which was directly related to the quantity of applied nutrients. Among organic sources, poultry manure at $5 \mathrm{Mg} \mathrm{ha}^{-1}$ resulted in the highest total P content in grain (Tab. II). In general, organic rice contained more phosphorus than the inorganic treatment, although kudzu compost, winter weeds and farmyard manure at $5 \mathrm{Mg} \mathrm{ha}^{-1}$ were at par with the inorganic treatment. Furthermore, application of $\mathrm{P}$ in soil leads to an increase in total $\mathrm{P}$ content but does not affect its conversion into phytic acid. This result is in agreement with the review by Worthington (2001), who reported that an organic crop was richer in phosphorous content compared with a conventionally grown crop.

\subsection{Minerals}

The potassium content in rice grain was highest due to organic treatments, which varied from $2390-2600 \mu \mathrm{g} \mathrm{g}^{-1}$ 
Table II. Protein content and per cent conversion of phosphorous to phytic acid in rice grain.

\begin{tabular}{lcccc}
\hline Nutrient source & Protein $(\%)$ & Total P $(\%)$ & Phytic acid $(\%)$ & $\%$ P-Phytic acid of total P \\
\hline Non-amended control & $7.55 \pm 0.08^{\mathrm{a}}$ & $0.194 \pm 0.014^{\mathrm{a}}$ & $0.363 \pm 0.006^{\mathrm{a}}$ & $53.81 \pm 6.78$ \\
Lantana compost-5 & $7.67 \pm 0.08^{\mathrm{ab}}$ & $0.238 \pm 0.025^{\mathrm{cdef}}$ & $0.379 \pm 0.012^{\mathrm{a}}$ & $46.06 \pm 4.80$ \\
Lantana compost-10 & $8.16 \pm 0.13^{\mathrm{cd}}$ & $0.248 \pm 0.019^{\mathrm{defg}}$ & $0.388 \pm 0.001^{\mathrm{ab}}$ & $46.68 \pm 4.73$ \\
Kudzu compost-5 & $7.77 \pm 0.13^{\mathrm{ab}}$ & $0.232 \pm 0.009^{\mathrm{bcd}}$ & $0.371 \pm 0.004^{\mathrm{a}}$ & $48.93 \pm 0.44$ \\
Kudzu compost-10 & $8.42 \pm 0.05^{\mathrm{e}}$ & $0.250 \pm 0.012^{\mathrm{fg}}$ & $0.374 \pm 0.001^{\mathrm{a}}$ & $46.07 \pm 2.76$ \\
Urtica compost-5 & $8.07 \pm 0.14^{\mathrm{c}}$ & $0.243 \pm 0.011^{\mathrm{def}}$ & $0.398 \pm 0.004^{\mathrm{ab}}$ & $47.23 \pm 2.35$ \\
Urtica compost-10 & $8.35 \pm 0.19^{\mathrm{de}}$ & $0.249 \pm 0.020^{\mathrm{efg}}$ & $0.387 \pm 0.007^{\mathrm{ab}}$ & $44.91 \pm 3.96$ \\
Winter weeds-2.5 & $7.82 \pm 0.15^{\mathrm{b}}$ & $0.223 \pm 0.013^{\mathrm{bc}}$ & $0.378 \pm 0.009^{\mathrm{a}}$ & $46.70 \pm 2.38$ \\
Winter weeds-5 & $8.42 \pm 0.06^{\mathrm{e}}$ & $0.234 \pm 0.004^{\mathrm{def}}$ & $0.419 \pm 0.001^{\mathrm{b}}$ & $48.81 \pm 1.25$ \\
Farmyard manure-5 & $7.63 \pm 0.21^{\mathrm{ab}}$ & $0.232 \pm 0.014^{\mathrm{bcde}}$ & $0.371 \pm 0.004^{\mathrm{a}}$ & $46.18 \pm 3.23$ \\
Farmyard manure-10 & $7.78 \pm 0.17^{\mathrm{ab}}$ & $0.242 \pm 0.022^{\mathrm{def}}$ & $0.388 \pm 0.001^{\mathrm{ab}}$ & $46.31 \pm 5.80$ \\
Poultry manure-2.5 & $7.70 \pm 0.12^{\mathrm{ab}}$ & $0.250 \pm 0.015^{\mathrm{fg}}$ & $0.374 \pm 0.010^{\mathrm{a}}$ & $49.71 \pm 2.03$ \\
Poultry manure-5 & $8.05 \pm 0.17^{\mathrm{c}}$ & $0.262 \pm 0.024^{\mathrm{g}}$ & $0.383 \pm 0.002^{\mathrm{a}}$ &
\end{tabular}

Mean \pm standard deviation of three replications; means in the same column with different letters are significantly $(P<0.05)$ different.

Table III. Mineral nutrient content of dehulled rice grain.

\begin{tabular}{|c|c|c|c|c|}
\hline Nutrient source & $\mathrm{K}$ & $\mathrm{Fe}$ & $\mathrm{Zn}$ & $\mathrm{Cu}$ \\
\hline Non-amended control & $0.235 \pm 0.008^{\mathrm{a}}$ & $41.67 \pm 0.15^{\mathrm{a}}$ & $14.17 \pm 0.76^{\mathrm{a}}$ & $2.71 \pm 0.13^{\mathrm{a}}$ \\
\hline Lantana compost- 5 & $0.249 \pm 0.012^{\mathrm{ab}}$ & $47.00 \pm 1.37^{\mathrm{def}}$ & $15.33 \pm 0.76^{\mathrm{abc}}$ & $3.16 \pm 0.14^{\mathrm{bc}}$ \\
\hline Lantana compost-10 & $0.260 \pm 0.010^{\mathrm{b}}$ & $52.23 \pm 1.00^{\mathrm{g}}$ & $15.67 \pm 0.29^{\mathrm{abc}}$ & $4.03 \pm 0.15^{\mathrm{ij}}$ \\
\hline Kudzu compost-5 & $0.249 \pm 0.003^{\mathrm{ab}}$ & $44.73 \pm 0.43^{b c}$ & $15.17 \pm 0.76^{\mathrm{abc}}$ & $3.11 \pm 0.07^{b}$ \\
\hline Kudzu compost- 10 & $0.260 \pm 0.005^{\mathrm{b}}$ & $46.10 \pm 0.80^{\text {bcde }}$ & $16.17 \pm 0.76^{\mathrm{bcd}}$ & $3.54 \pm 0.25^{\mathrm{efg}}$ \\
\hline Urtica compost-5 & $0.240 \pm 0.005^{\mathrm{a}}$ & $45.83 \pm 0.55^{\mathrm{bcd}}$ & $15.17 \pm 0.76^{\mathrm{abc}}$ & $3.53 \pm 0.12^{\text {efg }}$ \\
\hline Urtica compost- 10 & $0.250 \pm 0.010^{\mathrm{ab}}$ & $46.57 \pm 0.68^{\text {cdef }}$ & $15.17 \pm 0.29^{\mathrm{abc}}$ & $3.72 \pm 0.10^{\mathrm{fgh}}$ \\
\hline Winter weeds- 2.5 & $0.239 \pm 0.007^{\mathrm{a}}$ & $45.83 \pm 1.31^{\mathrm{bcd}}$ & $15.00 \pm 0.50^{\mathrm{ab}}$ & $3.79 \pm 0.15^{\mathrm{ghi}}$ \\
\hline Winter weeds-5 & $0.250 \pm 0.005^{\mathrm{ab}}$ & $48.31 \pm 1.51^{\mathrm{f}}$ & $16.50 \pm 0.50^{\mathrm{bcd}}$ & $3.88 \pm 0.09^{\text {hij }}$ \\
\hline Farmyard manure-5 & $0.242 \pm 0.007^{\mathrm{a}}$ & $47.27 \pm 0.91^{\mathrm{def}}$ & $16.67 \pm 1.53^{\mathrm{cd}}$ & $3.24 \pm 0.07^{\mathrm{bcd}}$ \\
\hline Farmyard manure-10 & $0.249 \pm 0.011^{\mathrm{ab}}$ & $48.00 \pm 0.20^{\mathrm{ef}}$ & $16.17 \pm 1.53^{\mathrm{bcd}}$ & $3.48 \pm 0.04^{\mathrm{def}}$ \\
\hline Poultry manure-2.5 & $0.244 \pm 0.010^{\mathrm{a}}$ & $44.67 \pm 1.65^{\mathrm{b}}$ & $15.83 \pm 0.29^{\mathrm{bc}}$ & $3.27 \pm 0.17^{\text {bcde }}$ \\
\hline Poultry manure-5 & $0.245 \pm 0.005^{\mathrm{ab}}$ & $46.60 \pm 1.45^{\text {cdef }}$ & $17.50 \pm 0.87^{\mathrm{d}}$ & $3.43 \pm 0.27^{\text {cde }}$ \\
\hline Inorganic & $0.238 \pm 0.015^{\mathrm{a}}$ & $42.10 \pm 0.27^{\mathrm{a}}$ & $15.50 \pm 0.50^{\mathrm{abc}}$ & $4.07 \pm 0.14^{j}$ \\
\hline
\end{tabular}

Content of potassium $(\mathrm{K})$ was expressed in per cent and iron $(\mathrm{Fe})$, zinc $(\mathrm{Zn})$ and copper $(\mathrm{Cu})$ were in $\mu \mathrm{g} \mathrm{g}^{-1}$. Mean \pm standard deviation of three replications; means in the same column with different letters are significantly $(P<0.05)$ different.

(Tab. III). The potassium content in the inorganic treatment was significantly lower than that of Lantana and kudzu compost at $10 \mathrm{Mg} \mathrm{ha}^{-1}$. This might be due to supply of more potassium through these two treatments (Tab. I). These two organic treatments yielded $2600 \mu \mathrm{g}$ potassium per $\mathrm{g}$ of rice grain.

An atomic absorption spectrophotometer was used to analyze iron content in rice grains of non-amended control and inorganic treatments, and they were similar (41.67 and $\left.42.10 \mu \mathrm{g} \mathrm{g}^{-1}\right)$. Organically grown rice was, however, significantly richer $\left(44.67-52.23 \mu \mathrm{g} \mathrm{g}^{-1}\right)$ in iron content than the fertilized treatment $\left(42.10 \mu \mathrm{g} \mathrm{g}^{-1}\right)$. This result is in contrast to the conclusion drawn by Woese et al. (1997) and Worthington
(2001). Among the organic sources, Lantana compost at $10 \mathrm{Mg} \mathrm{ha}^{-1}$ and winter weeds at $5 \mathrm{Mg} \mathrm{ha}^{-1}$ performed better than the other treatments and the former recorded the highest Fe content $\left(52.2 \mu \mathrm{g} \mathrm{g}^{-1}\right)$ compared with the other treatments.

The zinc content in rice grain varied from 14.17$17.50 \mu \mathrm{g} \mathrm{g}^{-1}$ across the treatments (Tab. III). However, it did not vary significantly among organic treatments. Poultry manure at $5 \mathrm{Mg} \mathrm{ha}^{-1}$ proved the best at enriching rice with zinc and it was significantly superior to the inorganic treatment. Zinc concentration in the latter was at par with non-amended control. Contrary to zinc concentration, copper content in inorganic rice $\left(4.07 \mu \mathrm{g} \mathrm{g}^{-1}\right)$ was significantly higher than all 
Table IV. Physico-chemical parameters of dehulled rice.

\begin{tabular}{|c|c|c|c|c|}
\hline Nutrient source & Hulling $(\%)$ & Milling (\%) & Head Rice recovery $(\%)$ & Kernel elongation ratio \\
\hline Non-amended control & $80.06^{\mathrm{def}}$ & $69.87^{\mathrm{def}}$ & $45.16^{\mathrm{d}}$ & $1.60^{\mathrm{abc}}$ \\
\hline Lantana compost-5 & $80.21^{\mathrm{def}}$ & $68.71^{\mathrm{c}}$ & $39.92^{\mathrm{a}}$ & $1.57^{\mathrm{abc}}$ \\
\hline Kudzu compost-5 & $79.28^{\mathrm{ab}}$ & $69.34^{\text {cde }}$ & $49.22^{\mathrm{f}}$ & $1.56^{\mathrm{ab}}$ \\
\hline Kudzu compost-10 & $79.89^{\mathrm{bcd}}$ & $69.14^{\text {cd }}$ & $41.15^{\mathrm{b}}$ & $1.62^{\mathrm{bc}}$ \\
\hline Urtica compost-5 & $82.32^{\mathrm{f}}$ & $72.58^{\mathrm{g}}$ & $47.99^{\mathrm{e}}$ & $1.56^{\mathrm{ab}}$ \\
\hline Winter weeds- 2.5 & $80.25^{\mathrm{de}}$ & $70.42^{\mathrm{f}}$ & $49.39^{f}$ & $1.57^{\mathrm{abc}}$ \\
\hline Winter weeds-5 & $79.58^{\mathrm{bcd}}$ & $70.07^{\mathrm{ef}}$ & $46.12^{\mathrm{d}}$ & $1.60^{\mathrm{abc}}$ \\
\hline Farmyard manure-5 & $80.69^{\mathrm{e}}$ & $69.66^{\mathrm{def}}$ & $47.43^{\mathrm{e}}$ & $1.60^{\mathrm{abc}}$ \\
\hline Farmyard manure-10 & $79.50^{\mathrm{bc}}$ & $70.17^{\mathrm{f}}$ & $47.33^{\mathrm{e}}$ & $1.61^{\mathrm{bc}}$ \\
\hline Poultry manure- 2.5 & $79.58^{\mathrm{bcd}}$ & $64.58^{\mathrm{a}}$ & $42.40^{\mathrm{c}}$ & $1.56^{\mathrm{ab}}$ \\
\hline
\end{tabular}

Means in the same column with different letters are significantly $(P<0.05)$ different.

Table V. Correlation between different physico-chemical parameters.

\begin{tabular}{|c|c|c|c|c|c|c|c|c|c|c|}
\hline & $\begin{array}{l}\text { Milling } \\
\text { recovery }\end{array}$ & $\begin{array}{c}\text { Head Rice } \\
\text { recovery }\end{array}$ & Kr. length & Kr. breadth & $\mathrm{L} / \mathrm{Br}$ & $\begin{array}{c}\text { Cooked kr. } \\
\text { length }\end{array}$ & $\begin{array}{c}\text { Cooked kr. } \\
\text { breadth }\end{array}$ & $\begin{array}{l}\mathrm{Kr} \text {. elongation } \\
\text { ratio }\end{array}$ & $\begin{array}{c}\text { Water } \\
\text { uptake no. }\end{array}$ & $\begin{array}{c}\text { Volume } \\
\text { expansion }\end{array}$ \\
\hline Hulling recovery & $0.619 *$ & 0.346 & -0.260 & 0.263 & -0.321 & -0.165 & 0.296 & 0.143 & 0.114 & 0.021 \\
\hline Head Rice recovery & & & 0.480 & 0.436 & -0.192 & 0.072 & 0.283 & 0.091 & 0.156 & $0.601 *$ \\
\hline Kr. length & & & & 0.296 & 0.471 & -0.55 & -0.005 & $-0.792 * *$ & -0.100 & 0.166 \\
\hline Kr. breadth & & & & & $-0.596^{*}$ & 0.169 & -0.046 & -0.122 & 0.304 & 0.020 \\
\hline Cooked kr. length & & & & & & & -0.148 & $0.619^{*}$ & 0.270 & -0.021 \\
\hline Cooked kr. breadth & & & & & & & & -0.028 & 0.270 & 0.239 \\
\hline Kr. elongation ratio & & & & & & & & & 0.175 & -0.092 \\
\hline Water uptake no. & & & & & & & & & & -0.312 \\
\hline
\end{tabular}

*, **: Correlation is significant at the 0.05 and 0.01 level, respectively; L: Length; Br: Breadth; Kr.: Kernel.

organic treatments (Tab. III). Copper content in the organic treatments was highest in Lantana compost at $10 \mathrm{Mg} \mathrm{ha}^{-1}$ (4.03 $\mu \mathrm{g} \mathrm{g}^{-1}$ ). On the other hand, the lowest copper concentration was recorded with kudzu compost at $5 \mathrm{Mg} \mathrm{ha}^{-1}$ (3.11 $\mu \mathrm{g} \mathrm{g}^{-1}$ ), which, however, was significantly better than control $\left(2.71 \mu \mathrm{g} \mathrm{g}^{-1}\right)$.

\subsection{Physico-chemical properties}

Based on the length and breadth of the grain, the rice genotype used in the present investigation was characterized as aromatic with long and bold type. Variations in the physicochemical parameters of the rice grain as influenced by nutrient sources were significant (Tab. IV). The variety contained satisfactory milling recovery, which ranged from 66.9-72.6 per cent in different treatments, except poultry manure at 2.5 and
5.0 $\mathrm{Mg} \mathrm{ha}^{-1}$, which had only 65 per cent milling out-turn. Hulling recovery was positively correlated with milling outturn (Tab. V), whereas head rice recovery showed no correlation with hulling or milling quality. Kernel elongation exhibited a positive relationship with cooked kernel length.

Hulling and milling quality due to nutrient sources differed significantly in some cases. Total hulled and milled rice recovery was highest with application of Utrica compost at $5 \mathrm{Mg} \mathrm{ha}^{-1}$ and significantly better than all other treatments. In general, lower doses of organic manures recorded better hulling quality than higher doses.

In the case of head rice recovery, kudzu compost at $5 \mathrm{Mg} \mathrm{ha}^{-1}$ was found to be the best among all the treatments with 49.2 per cent out-turn. Quyen and Sharma (2003) also reported an increase in head rice recovery and the length-breadth ratio in organic treatment. Different sources and levels of nutrients had no significant influence on kernel elongation. 


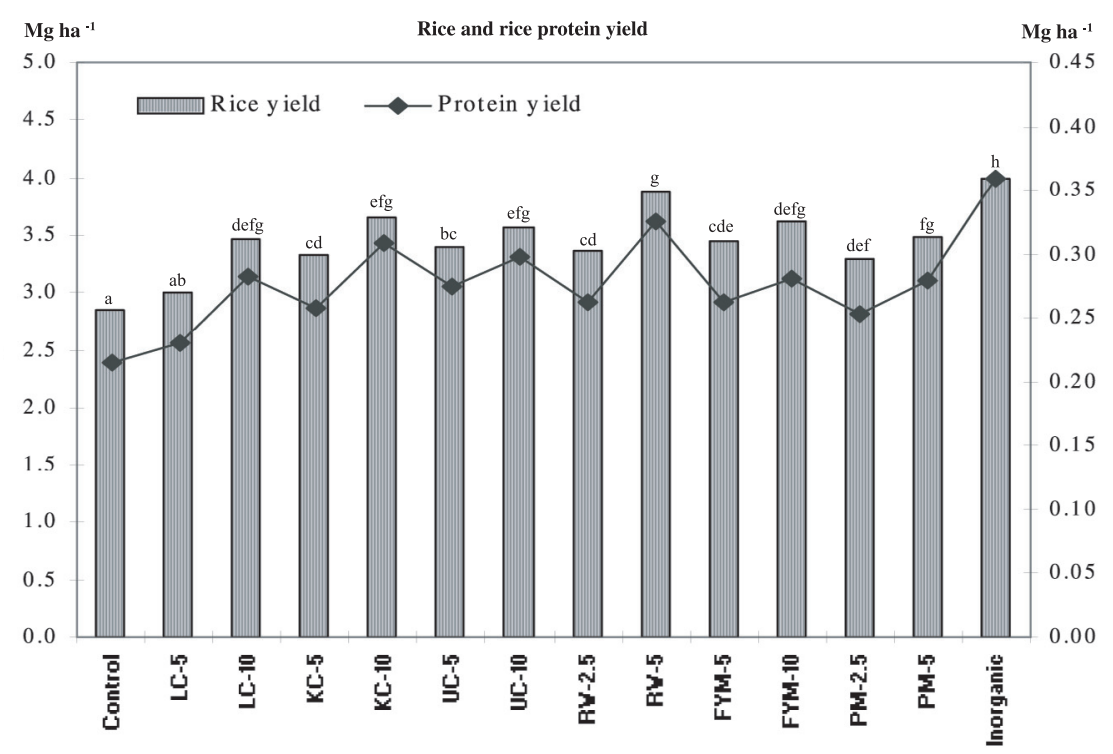

LC-5, 10: Lantana compost @ 5, $10 \mathrm{Mg} \mathrm{ha}^{-1}$ UC-5, 10: Urtica compost @ 5, $10 \mathrm{Mg} \mathrm{ha}^{-1}$; $\quad$ RW-2.5, 5: Winter weeds @ 2.5, $5 \mathrm{Mg} \mathrm{ha}^{-1}$;

KC-5, 10: Kudzu compost @ 5, $10 \mathrm{Mg} \mathrm{ha}^{-1}$; FYM-5, 10: Farmyard manure @ 5, $10 \mathrm{Mg} \mathrm{ha}^{-1}$; PM-2.5, 5: Poultry manure @ 2.5, $5 \mathrm{Mg} \mathrm{ha}^{-1}$ Bars with different letters are significantly $(P<0.05)$ different

Figure 2. Yield of milled rice and protein across the treatments.

\subsection{Grain yield}

The milled rice yield varied between 3.01 and $3.87 \mathrm{Mg} \mathrm{ha}^{-1}$ in various organic nutrient treatments (Fig. 2). Non-amended control produced the lowest rice yield and was significantly inferior to all other treatments except Lantana compost at $5 \mathrm{Mg} \mathrm{ha}^{-1}$. Rice yields obtained with winter weeds at $5 \mathrm{Mg} \mathrm{ha}^{-1}$ and the inorganic treatment were significantly higher than other treatments, in which inorganic treatment yielded the highest milled rice production $\left(4.00 \mathrm{Mg} \mathrm{ha}^{-1}\right)$. Increase in the yield is mostly due to more availability of nutrients through inorganic fertilization. This result is in contrast with the report that spring cereals have similar yield levels with organic and mineral fertilization (Raupp, 1996). Among organic treatments, winter weeds at $5 \mathrm{Mg} \mathrm{ha}^{-1}$ proved to be the best. Sharma et al. (2003) also reported that additions of residues of Lantana camara at 10, 20 and $30 \mathrm{Mg} \mathrm{ha}^{-1}$ increased rice yields on average by 18, 23 and $30 \%$, respectively, as compared with control in a rice-wheat cropping system. The protein yield ranged from $215-359 \mathrm{~kg} \mathrm{ha}^{-1}$ across the treatments (Fig. 2). Protein yield in inorganic rice was the highest $\left(0.36 \mathrm{Mg} \mathrm{ha}^{-1}\right)$. Among organic treatments, winter weed compost application at $5 \mathrm{Mg} \mathrm{ha}^{-1}$ performed better than the others in terms of protein yield $\left(0.33 \mathrm{Mg} \mathrm{ha}^{-1}\right)$.

\section{CONCLUSION}

It has been established that yield and protein content in rice grain was influenced significantly by the sources of nutrients and that it was richer in conventionally grown rice than organic rice. Inorganic treatment was superior in terms of cop- per content. However, application of Lantana and kudzu composts, each at $10 \mathrm{Mg} \mathrm{ha}^{-1}$, recorded the highest potassium content. The concentration of phosphorus in the rice varied significantly with applied nutrient levels and in general organic treatments were better than inorganic treatment. However, it was not the same in terms of phytic acid content. Iron content was significantly higher in organic than inorganic treatment. As regards physico-chemical properties, milling recovery was significantly correlated with hulling, and cooking kernel length with the kernel elongation ratio. The results of this study suggest that organic nutrient sources can perform comparatively well as regards chemical and physico-chemical properties, and cooking quality of rice, if not better in some parameters than inorganic sources. Among organic composts, winter weed compost performed better than the other organic treatments at elevating the yield and nutritional quality of rice (protein, iron content and head rice recovery) despite winter weed compost adding less nutrients than other organic composts. The universal desire for sustainable agriculture may be fulfilled only through organic farming. Use of natural resources and their recycling is a better alternative to achieve sustainability. Our results indicate that winter weed composts can be used for betterment of yield and nutritional quality of organically grown rice.

Acknowledgements: The authors are thankful to Dr. M.P. Pandey, Dept. of Genetics, G.B.P.U.A. \& T., Pantnagar, UA, India and Mr. Sanjay Kumar, for their help with analysis.

\section{REFERENCES}

AOAC, (1990) Official Methods of Chemical Analysis, Association of Official Analytical Chemists, 15th ed., Arlington. 
Artur G., Kjellenberg L. (1997) Long-term field experiments in Sweden: effects of organic and inorganic fertilizers on soil fertility and crop quality, in: Proceedings of the International Conference on Agricultural Production and Nutrition, March 1997, Boston, Massachusetts.

Bourn D., Prescott J. (2002) A comparison of the nutritional value, sensory qualities, and food safety of organically and conventionally produced foods, Crit. Rev. Food Sci. Nutr. 42, 1-34.

Hachicha S., Chtourou M., Medhioub K., Ammar E. (2006) Compost of poultry manure and olive mill wastes as an alternative fertilizer, Agron. Sustain. Dev. 26, 135-142.

Hidvegi M., Lasztity R. (2002) Phytic acid content of cereals and legumes and interaction with proteins, Periodica Polytechnica Ser. Chem. Eng. 46, 59-64.

Kayuki C.K., Wortmann C.S. (2001) Plant materials for soil fertility management in subhumid tropical areas, Agron. J. 93, 929-935.

Kolawole G.O., Tijani-Eniola H., Tian G. (2004) Phosphorus fractions in fallow systems of West Africa: Effect of residue management, Plant Soil 263, 113-20.

Lees R. (1975) Food analysis. Analytical and quality methods for the food manufacturers and buyer, 3rd ed., Leonard Hill Books, London.

Li Z., Wan J., Xiao J., Yano M. (2003) Mapping of quantitative trait loci controlling physico-chemical properties of rice grain (Oryza sativa L.), Breeding Sci. 53, 209-215.

Little R.R., Holder G.B., Dawson E.H. (1958) Differential effect of dilute alkali on 25 varieties of milled white rice, Cereal Chem. 35, 111126.

Magkos F., Arvaniti F., Zampelas A. (2003) Organic food: nutritious food or food for thought? A review of the evidence, Int. J. Food Sci. Nutr. $54,357-371$.

Mekki A., Dhouib A., Aloui F., Sayadi S. (2006) Olive wastewater as an ecological fertiliser, Agron. Sustain. Dev. 26, 61-67.

Miller G.A., Young's V.L., Plunger E.S. (1980) Environmental and cultivar effects on oat phytic acid concentration, Cereal Chem. 57, 189191.

Nziguheba G., Merckx R., Palm C.A., Rao M.R. (2000) Organic residues affect phosphorus availability and maize yields in a Nitisol of western Kenya, Biol. Fert. Soils 32, 328-339.
Oatway L., Vasanthan T., Helm J.H. (2001) Phytic acid, Food Rev. Int. 419-431.

Page A.L., Miller R.A., Keeney D.R. (1982) Methods of soil analysis, Part 2, Chemical and microbiological properties, 2nd ed., Agronomy No. 9, ASA-SSSA, Madison, Wisconsin.

Patnaik G. (1996) Problems and prospects of developing exports of organically produced agro products, in: Proceedings of the National Workshop on Organic Farming for Sustainable Agriculture, 1820 Jan 1996, Central Research Institute for Dry land Agriculture, Hyderabad, India.

Quyen N., Sharma S. (2003) Relative effect of organic and conventional farming on growth, yield and grain quality of scented rice and soil fertility, Arch. Agr. Soil Sci. 49, 623-629.

Raupp J. (1996) Discussion: Fertilization effects on product quality and examination of parameters and methods for quality assessment, in: Raupp J. (Ed.), Quality of plant products grown with manure fertilization, Proc. 4th Meeting Concerted Action Fertilization Systems in Organic Farming (AIR3-CT94-1940), Juva, Finland, 6-9 July 1996, pp. 44-48.

Sharma P.K., Ladha J.K., Verma T.S., Bhagat R.M., Padre A.T. (2003) Rice-wheat productivity and nutrient status in a lantana- (Lantana spp.) amended soil, Biol. Fert. Soils 37, 108-114.

Taussky H.H., Shorr E. (1953) A microcolorimetric method for the determination of inorganic phosphorus, J. Biol. Chem. 202, 675-682.

Walkley A., Black J.A. (1934) Estimation of soil organic carbon by chromic acid titration method, Soil Sci. 17, 29-38.

Wheeler E.L., Ferrel R.E. (1971) A method for phytic acid determination in wheat and wheat fractions, Cereal Chem. 48, 312.

Woese K., Lange D., Boess C., Boegl K.W. (1997) A comparison of organically and conventionally grown foods- results of a review of the relevant literature, J. Sci. Food Ag. 74, 281-293.

Worthington V. (2001) Nutritional quality of organic versus conventional fruits, vegetables and grains, J. Alter. Comp. Med. 7, 161-173.

Wszelaki A., Delwiche J.F., Walker S.D., Ligget R.E., Scheerens J.C., Kleinhenz M.D. (2005) Sensory quality and mineral and glycoalkaloid concentration in organically and conventionally grown redskin potatoes (Solanum tuberosum), J. Sci. Food Ag. 85, 720-726. 